\title{
CARTESIAN SUBJECTS LOST IN THE ALPS REFLECTIONS ON RUBEN ÖSTLUND'S FORCE MAJEURE
}

\section{Sven Anders Johansson}

\begin{abstract}
The article analyses the constitution of subjectivity in Ruben Östlund's film Force Majeure (2014). At the centre of attention stands the male protagonist who is uncapable of reconciling his inner nature with the external expectations. If the film may be understood as a critique of existing middle-class conventions, it also reproduces a highly conventional ideal of the self-identical subject. The article argues that this confusion or irony is an expression of a Cartesian subject - still prevalent in the film - in crisis. A neglected aspect of Descartes' theory is that the autonomy of the subjects presupposes the existence of God. The problem for Östlund's characters is that there is no God. Still, they act as if he, or as if any authority might, legitimize their subjectivity. Thus, the whole existence becomes a series of performances. The idea of an inner nature corresponds with the notion of an outer nature. The latter is certainly very present in Force Majeure, but at the same time this nature is constantly problematized. On an allegorical level, the film may thus be read as a comment on the Anthropocene, a state where we no longer know neither what "nature", nor "culture" is.
\end{abstract}

\section{KEYWORDS}

Ruben Östlund, Subjective Impotence, Inner Nature, Cogito, Second Nature, Anthropocene, Theodor W. Adorno, Timothy Morton

I

In a talk show on Swedish Public Service Radio in 2017, Ruben Östlund discussed a scene in his, at that time, forthcoming film The Square. In the scene, a disconcerting art performance is taking place during an elegant gala banquet. A performance artist is acting like a wild animal, a monkey, or, as Östlund puts it, "a human being who has been stripped of his civilized veneer. What remains is just instincts and drives." ${ }^{1}$ More concretely, the barechested artist jumps around between the dressed-up dinner guests like a big ape. Sniffing, tinkering, investigating - acting like a wild animal might act, scaring the dinner guests, chasing a man out of the room, before taking an interest in a woman. Gradually he 
initiates a sexual assault on her. Despite her half-hearted cries for help, no one does anything, until finally, at the last moment, a few men rush up and furiously overpower the "monkey", drowning him with punches while shouting about killing him.

To Östlund, this scene illustrates a conflict between nature and culture, instincts and civilized manners. The human being, Östlund explains, is governed by instincts and drives at the same time as it is forced to act according to certain cultural roles, roles that are mediated by mass media and cultural products of different kinds. The result is discomfort, shame, and awkwardness of various degrees. This is a conflict that can be observed in several of Östlund's films, not least in Force Majeure (2014), which will be the focus of attention here. This film revolves around a family (Tomas, Ebba, and their two children) on a ski vacation in the Alps. In the central scene, the family is having lunch on the terrace of a restaurant when an avalanche, triggered intentionally, approaches from the opposite mountainside. Tomas assures his worried wife that they are safe, that everything is under control. When the avalanche does not stop, but instead seems to threaten the restaurant and the panic is spreading, it is nevertheless he who rushes up and escapes, leaving his family to fend for themselves.

Just a few weeks before Östlund's radio talk, the former Swedish Minister of Finance, Anders Borg, issued a public apology for making a fool of himself at a private party. According to reports in the media, Borg, being very drunk, had acted aggressively towards other guests, calling a number of women "whores," grabbing male guests in the crotch, and displaying his own genitals. When the rumours reached the press, Borg made an excuse on his Facebook profile: "I have heard, in retrospect, that I acted very inappropriately," he wrote, "I sincerely want to apologize to the people present who took offense. Feel great disappointment and repentance for my behaviour.”2

The reason for bringing up Anders Borg here is that his behaviour - above all his excuse - was an interesting echo of the behaviour of Tomas in Force Majeure. If the avalanche scene is the peripeteia of the film, there is a second turning point when Tomas finally, after stubbornly having denied his spineless escape, breaks down and confesses - we could call this the crying scene. Trying to make sense of his actions, he starts talking about himself as two persons: "I get it that you're disappointed in the person who has materialized," he says to his wife, as if this "person” was someone else. "I'm really disappointed in him too. I hate him.” 3 (1:34:35). He then starts to weep for real, unable to control his body, sobbing "like 
a child struck by emotions," as it says in the published script.4 "I'm a victim too! I'm a bloody victim of my own instincts!” (1:35:27).

What we have here, is the same divided subject as in the Borg case - a reflecting self and its instincts. A man who is disappointed (the phrase used by Borg is almost the same as Tomas') in himself, in his own actions. What is noteworthy, is that both characters deprive the self of the responsibility for the actions that it simultaneously admits to have performed. Borg apologizes and throws the blame away at the same time: he had a "black out," and he feels "disappointment." In exactly the same way, Tomas' excuse implies that he should get away with his actions. Instead of taking responsibility, he treats himself as a victim of his instincts. Just like Borg, he is disappointed, "disappointed in him," as if there were two persons without influence on each other.

Perhaps this could be described as a new kind of subjective impotence: successful men in their prime, who suddenly cannot account for themselves and their actions ${ }^{5}$ - the case with the Swedish minister of finance, being a good non-fictive example. (If one wants more examples, the \#metoo campaign, and the explanations and excuses generated by it, is a good place to look.) It is as if we are gradually becoming some kind of extras in our own lives, as if we are alien in relation to our own behaviour.

In order to analyse this further, one could of course turn to Freud, his dissection of the human subject, the invention of the unconscious, and the observation of an ego that is no longer a master in its own house. ${ }^{6}$ This is not the way taken by Östlund though. If we regard Force Majeure as an investigation, a case of artistic research in subjective shortcomings, it does not enter into the realm of the unconscious, dreams, and repressed sexuality. Of course, one may still go ahead and "read" the film from that perspective, but that is not the route I am taking here. The reason for this is that I am interested not only in "Tomas" as a symptom, but also in the model of thinking, adopted by Östlund, the ideological matrix reproduced by Force Majeure. Not because it is original, but on the contrary, because I think his model of thinking is typical for our times.

According to this ideology, the cultural roles we play should be in accordance with our inner nature (men should be men, selfidentity is what we should strive for, and beneath all culture we find nature, which consists of instincts, desire, animalism...). When Östlund himself talks about his films, this impression is actually strengthened. ${ }^{7}$ This aspect is also highlighted, time and time again, in the reception of Force Majeure. ${ }^{8}$ It is hence not farfetched to argue that this is an explanation for its success: the 
film lets us laugh at the middle-class behaviour (i.e. at ourselves), at the same time as it confirms, rather than threatens, the ideology and the understanding of subjectivity on which this behaviour (our behaviour) relies. This is an ideology that, in short, confirms the individual as a natural entity - that is, something stable, something that is just there - and discards all political aspects and explanations as secondary.

This understanding has arguably gained impact during the last decades, partly due to advances in the natural sciences. The human genome has been mapped out, the biochemical premises for our feelings have been more and more well documented; the diagnoses that define our personal peculiarities are proliferating. Now, more than ever, we are able to explain biologically what lies behind the actions and feelings of the subject, and hence do away with the unwanted sides of life. Even death may be pushed into a far future. However, the more knowledge we gain about the biological premises of our human behaviour, the more powerless the human subjects become; the agency no longer resides in me or "Tomas" or "Anders," but in our genes and nervous system, in the smallest constituents of our brain cells. The subjects thus turn into objects. In a way this implies that we can no longer be held responsible for our own actions, because they are grounded on a molecular level. We can hardly even feel ashamed - just like Tomas and Anders, we can only feel what we feel after a bad concert or a mediocre dinner: disappointment.

Against that background it might be wrong to describe the "subjective impotence" depicted in Force Majeure as a new phenomenon. The impotence is simply a part of what it means to be a human being of flesh and blood, and hence not new at all. What is new is rather the political and ethical expectations on the subject, connected with a neoliberal ethos and an economization of the subject. "As human capital, the subject is at once in charge of itself, responsible for itself, yet an instrumentalizable and potentially dispensable element of the whole," as Wendy Brown puts it. ${ }^{9}$ If there is no such thing as society, not even a people, no "demos," the autonomous subject is left on its own. Subjective freedom hence coincides with unbearable responsibility. As Theodor Adorno writes half a century earlier: "The more freedom the subject - and the community of subjects - ascribes to itself, the greater its responsibility; and before this responsibility it must fail in a bourgeois life which in practice has never yet endowed a subject with the unabridged autonomy accorded to it in theory. Hence the subject must feel guilty." 10 If this was discernible already in the 
1960s, the point here is that this tendency has only been amplified ever since. Today the individual subject should not only be able to narrate its own story, to create itself according to its own will, but also to solve all the problems that are exterior to it: refugee crises, segregation, domestic violence, climate change, etc. The subject has become powerless and omnipotent at the same time. This is, I would argue, the predicament of the subjects in Force Majeure, and the background to the disappointment expressed by both Tomas and Anders Borg.

But let us linger for a while on the idea of a split subject, a subject that is both natural and cultural, that is torn between instincts and conventional demands. Where does this idea come from? One might point to Rousseau's ideas of a state of nature; to Vico's distinction between God's knowledge (of Nature) and human knowledge (of civil institutions), giving rise to natural sciences and the humanities as the two forms of knowledge corresponding to them; to the Christian idea of a flesh that is weak and a soul that should be saved; to Plato's distinction between the idea and the matter; and so on. The line could be drawn very far back in history.

More important in this context, however, is René Descartes. In his Discourse on Method, in reflecting upon his own subject, he concludes that "this 'I,' that is to say, the mind, by which I am what I am, is entirely distinct from the body." 11 If Descartes, at least according to the schoolbook version, inaugurates the autonomous, modern subject, he simultaneously splits this subject in two. The mind is totally alienated from the flesh. Or as he puts it a few pages further ahead in the text: "intelligent nature is distinct from the corporeal." 12

This is the matrix not only for the subject painted in Force Majeure (the civilized and successful husband, a victim to his own instincts), but also for Östlund's own explanations and interpretations. In commenting on his films, he reproduces this distinction over and over again. And yet it is not that easy to say where he is going with this. Take for example the scene where Tomas is skiing off-piste with his macho friend Mats. It is after the avalanche scene, but before the crying scene; in other words, Tomas is in limbo, a state of denial. They climb a mountain while talking about feelings. At the top Mats suggests that Tomas should try to scream. Scream out loud; let everything go in a primal scream, the idea being that inner nature should be released while being out there in the wilderness, far away from all culture. Tomas tries, hesitatingly at first, but then really puts himself in to it, crying out desperately. 
As so often in Östlund's films, there is something unclear regarding how this scene wants to be understood.13 Notwithstanding all the statements about our inner nature being at odds with the conventions ("wild and uncivilized nature", "What remains is just instincts and drives”), there is something vaguely sarcastic about this scene. ${ }^{14}$ Is not Tomas more conventional, more distanced from nature than ever, when he obeys the cheesiest of lifestyle advice? And is not this what the scene tries to tell us? In other words, it is as if the film makes fun of the ideology that it itself adheres to.

Another example is an enigmatic, short, wordless sequence in which a number of aggressive men suddenly are running toward Tomas, who tries but fails to escape. In the next shot he is standing in what appears to be a night club, in the middle of a group of screaming, jumping, puking, half naked men, pouring beer on each other. These scenes have no connection to the plot; the sequence is like a short eruption of testosterone or "male nature" bursting forth, confirming the most commonplace idea of "masculinity." Christian Gullette, who in his dissertation focuses on the queerness in Östlund's films, describes it as “one of the film's most ironic moments." 15 From that perspective, the viewer is invited to laugh at the hypermasculine cliché. This might be a plausible reading, but it is nevertheless hard to make sense of these scenes. As Gullette writes, it is "difficult to tease out exactly how queerness, to varying degrees, either deconstructs or recuperates masculine norms, or leaves the question unanswered and ambiguous." 16

This ambiguity is, I would argue, present throughout the film: on the one hand, nature is treated as something that still subsists within us, at least within "us" men. Every now and then it bursts forth, like when the husband instinctively escapes the threatening avalanche. On the other hand, the idea of such a nature is painted as a ridiculous cliché. It is as if the film wants to say something about masculinity, male identity, and nature; but it does not know what to say. (Is "male nature" a laughable cliché or is it what Swedish men need to recuperate?). It just throws up the cards in the air and hopes for the best.

Hence, another possibility slowly appears: Regardless of Östlund's intention, Force Majeure is a film lamenting or struggling with the absence of nature. This is the real reason for Tomas' angst: not that he is a victim to his inner nature, but that he is a simulacrum like all the rest of us. Underneath the cultural veneer there is just more veneer. When he tries to get in contact with his inner nature through the primal scream, or when he fakes crying, just as when he cries for real - he is more conventional than ever, just like Anders 
Borg was giving in to cultural stereotypes and sexist clichés - rather than to inner instincts - when he exposed his genitals.

In this perspective, the crucial question of the film can be formulated a bit differently: How can one be real or true or genuine when there is no nature anymore? What becomes of the realistic film character when there is no "reality" below the surface? When there are only roles, images, conventions, with nothing underneath them? What is left of the Cartesian subject when it has lost track of its own inner nature?

\section{II}

If we are to take Östlund's Cartesianism seriously, we should bear in mind that there is another, often foreseen, instance or authority involved outside of the split subject. In the fourth meditation, Descartes writes: "there must of necessity be another more perfect [being], upon whom I depended, and from whom I had acquired all I had." 17 To Descartes, this being is God: "that the things we grasp very clearly and very distinctly are all true, is assured only because God is or exists, and because he is a perfect Being, and because everything that is in us comes from him."18 Even if my subjective existence is confirmed by my own thoughts ("cogito..."), it is God who makes my thoughts and my body possible, it is God who makes things hang together. Without God there would be no Cartesian subject. (It might thus be debated how modern the subject established by Descartes really is. Étienne Balibar certainly has a point, when he argues that when Descartes is said to inaugurate the modern subject, it is actually because the later Kantian subject is projected onto his text). ${ }^{19}$

Another turn of this argument would be to question the presumed autonomy of the modern subject. This is in a way what Östlund's film does - as we have seen, the subjects are not in control. Is there something like a God in Force Majeure then? Something that can give unity to the miserable, powerless subjects? No, no God. That is the root of the problem. But maybe there is something that fills the same function. The thing is, that most actions in the film are performed as if they were to be watched or judged by someone. In the very first scene, the family is being photographed. After some instructions from the photographer, they succeed in performing the happy family in front of the camera. (The scene may be seen as an allusion to the first scene in Ingmar Bergman's Scenes from a Marriage, which starts in the same way with the family trying to perform their happiness in front of a photographer. ${ }^{20}$ It is just that the willingness to perform, to follow the instructions, is so much 
stronger four decades later). This actually sets the tone of the whole film, and it is as if the characters - above all Tomas - throughout the film are busy trying to act as themselves, to play their roles convincingly. As if the aim of the whole vacation is to stage the happy family life, to live up to the idea of the family in a platonic sense, to become authentic, i.e. natural. That quite a few scenes take place in front of the bathroom mirror at the hotel is significant; the family becomes real to itself only when the members are able to watch the image of themselves together.

This is, one might argue, what bourgeois subjectivity has always been about (and hence, as stated above, Östlund's "critique" is a commonplace). Everyone is forced to perform his or her own persona, play his or her role - that is modernity for you. ${ }^{21}$ But if we stick to the Cartesian perspective, the light becomes a bit different. The subjective existence is necessarily conditioned by a higher instance, something that confirms its actions from outside. We may not understand ourselves as Cartesians anymore, but maybe we still are to a great extent. 22 At least if we are to believe Östlund's films, and all his statements about his films, the self-understanding of the contemporary (Swedish) middle-class subject is structured in that way. This implies not only a distinction between cultural role and inner nature, but also this gaze from above. The subjective performances are always directed to God, even though he has long since died. "God" may hence be understood as a metalevel, an existence of another order, an order that is simply necessary for the subjective performances to be meaningful at all.

This becomes more concrete in a scene where Tomas and Ebba use the corridor to discuss their issue without the children. A caretaker at the hotel is silently watching them from a floor above while smoking a cigarette. Annoyed by his presence Ebba confronts him: "Can we have some privacy?" (A strange request, given that their private room is on the other side of the door). Tomas adds: "What do you want?!" (35:31). This question is interesting, because it actually makes a lot of sense in relation to the Cartesian matrix. The one who asks the question is the subject who cannot cope with himself, who feels like a victim of his own instincts. Hence, he asks the instance above him (God): what do you want with me? Why am $I$ acting like this? Why do you do this to me? Seen in this way, it is the premodern subjectus, turning to his Father, asking why this is happening to him. But there is no answer, only silence. "God" puts his cigarette out and walks away. The subjectus is left to himself. In contrast to Descartes (whose cogito was merely a function of Gods universe, a helpless effect of God's will), Tomas is living in a 
God-forsaken modern world; he has to establish his own existence. But he fails, since he cannot find anything real or true in his own subjective existence, and neither can he live up to the conventional expectations. So, he falls apart. The cogito trick does not work.

But Tomas and Ebba struggle to find a solution. If there is no God, maybe something else - basically any subject - can confirm them? Maybe the important thing is the transcendent gaze, a gaze from above or outside? On the last day of skiing, as the family is out on the slopes together, they make a try. As a real father figure Tomas is taking the lead, the children following him. What takes place now, we realize afterwards, is another enactment, where the apparent intention is to rehabilitate Tomas as a husband, father, and male. The weather is very foggy, and suddenly Ebba is no longer with them. They wait and shout her name. A faint answer from far away can be heard. Tomas gets rid of his skis and runs uphill. The camera stays with the children. After a rather long time Tomas slowly appears again through the fog, now carrying Ebba in his arms. When they reach the children, he puts her down on her feet and they all hug. And then - which of course discloses the whole enactment - she has to return up the hill (apparently not hurt at all) to fetch her skis that were left behind. In this scene, the observers are the children, who watch Tomas "saving" his wife. No matter if they see through the parent's theatrical act or not, the enactment is meaningful as long as they do not object but play their role and observe Tomas in action. There is no God, but any gaze might do - that is the plan, at least - in order to reinstall the responsible, accountable, consistent subject.

In the very last scene of the film, this logic is taken to another level. The scene takes place on a bus driving down the narrow mountain roads. The vacation is over, everyone is on their way home. But the ride does not go as planned. In one of the sharp curves the bus is on the verge of running off the road. When attempting to back off from the cliff, the incompetent driver fails making the gearshift with the result that the bus runs forward instead of backwards, even closer to the abyss. Ebba panics, and after some turmoil everyone (except one woman) leaves the bus, which then continues down the curvy mountain road. The abandoned passengers start walking.

How should this scene be read? In his ethical reading of Force Majeure, Jakob Lothe argues that the last scene is reconciliatory and positive. ${ }^{23}$ But is it really? As a part of the plot it is, once again, indeed illogical (Where are they walking? Why do they not call for help? How come they left their luggage on the bus?). So why is the scene there at all? 
The answer might be twofold. Firstly, the scene is there to create a certain balance: Ebba's escape from the bus is a parallel to Tomas' escape from the avalanche. In other words, the scene demonstrates that she is a victim to her instincts too, egoistically leaving her children behind on the bus. In that sense, the scene contributes to the rehabilitation of the male figure that has been ridiculed throughout the film. In the end, he is not the only subject acting instinctively selfish. So, after having ridiculed masculinity throughout the film, Östlund finally helps him up, basically saying that women are just as bad.

Secondly, and more importantly, the bus scene is there to generate the final image: everyone walking together toward the camera, as a collective. Fig 1

Even though the bus did not crash, this image certainly has the feel of "after the disaster." However, looking closer the people walking toward the camera do not really look like ski tourists, nor like near victims of a traffic accident, either in how they are dressed or in how they act. There is something in the image reminiscent of refugees walking away from a war or a flood or a terrorist attack - a child is being carried, everyone is serious, as if they escaped from a threat and are now walking toward an unpredictable future only this time, it is "us" (white middle-class Europeans) not "them" (African or Syrian refugees) who are on the run.

At the same time, they all seem relaxed. Serious, but content. Cool. It is as if they had reached a truer relation with their own selves. More in tune. Reconciled, to use Lothe's word. As Roger Edholm points out in his article in this issue, the music in the scene stands out from the frenetic Vivaldi score in the rest of the film. ${ }^{24}$ First there is silence, and then, at the very end, a more harmonious score is slowly building up, creating an almost sacred atmosphere. Coolness, harmony, togetherness - the result is something reminiscent of a commercial trying to sell us jeans, cigarettes, or pension funds.

In that sense, this scene is a type of enactment too, but at another level. This time, it is directed not to some of the characters in the film, but to us, the viewers. It is we who should be impressed and convinced, we who should confirm the actions and authenticity of the subjects walking toward the camera. What then does the scene want to tell us? What is it that we should confirm? In short, all the identities and units that were threatened: the family, the male identity, the authentic middleclass guy, social community, ethics, humanity. Here they are, all restored by our gaze. 

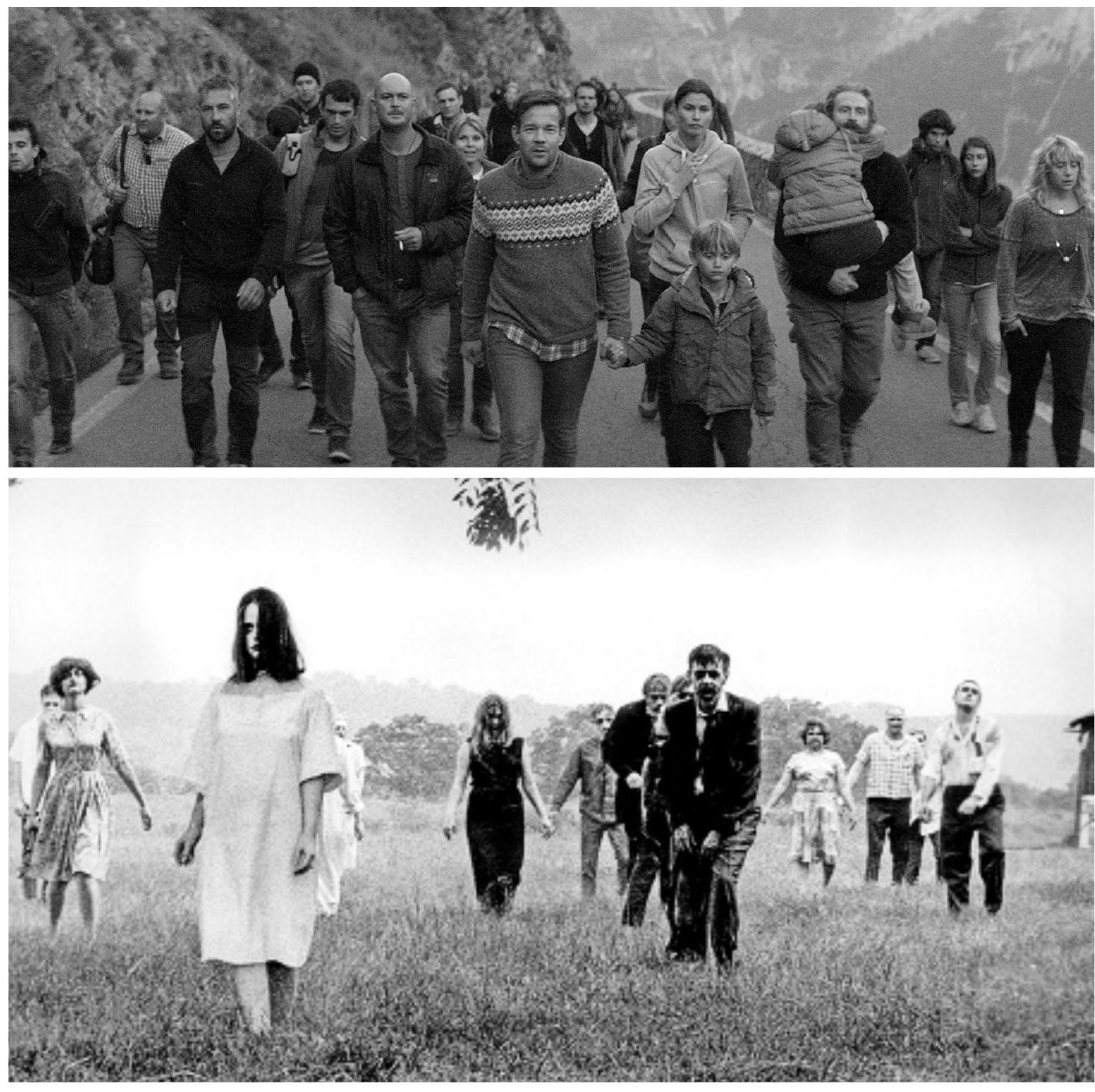

Fig. 1

(Force Majeure, 1.57.10)

Fig. 2

From Night of the Living Dead, directed by George A Romero, Image Ten Productions, 1968 
But does it work? As long as we stay within the frames of the middle-class ethics that is depicted, maybe it does. Put differently, the ending is reconciliatory in the same way as commercials are. But even the fictive characters themselves know that it is all fake, that this ethics can only be upheld through phony charades. And just as unlikely as it is that the children do not see through the ski slope charade described above, just as hard is it to accept the reconciliation of the final shot. Is there not in fact something strange, almost scary, about the subjects walking toward us? It is getting dark, everything is a bit grey. The people approaching the camera appear like a pack rather than a collective, walking one by one rather than together. They are almost silent, serious, but also lost, out of context, not in touch. It is almost as if they were sleepwalking. Is there not something in this shot reminiscent of another genre? Fig 2

The similarity to zombie films is not really as long a shot as it might appear. At least according to Timothy Morton, there is a connection between the zombie and the Cartesian subject: "There is an experiential valley where beings such as zombies live in between peaks: we 'healthy' humans live on one peak, and all the cuter robots on the other. Zombies live in the uncanny valley because they ironically embody Cartesian dualism: they are animated corpses. They are 'reduced' to object status." 25 What remains of the Cartesian subject in a God forsaken world? An animated corpse, trying to perform individuality and life. And animated corpses are just what Tomas and his pack are. In the last scene this finally becomes evident, both to them and us. Without a God, there is nothing that can keep them together, neither as a group nor us individual subjects. They are walking dead.

III

If what has been said so far mainly concerns the relation to something that could be designated "inner nature," it is also the case that Force Majeure, in it is entirety, is being played out with "outer nature" as a recurring background. One could even say that this outer nature is the real protagonist of the film, manifesting itself through mountains, forests, avalanches, sunshine, fog, snowfall, etc. Just like the classic Western movies had to present, or construct, the American nature as the silent background of the plots in order to tell the story of the conquering of the Wild West, Force Majeure tells the story of the Alps - the natural conditions for the characters being where they are. 
There is a logic in this, a correspondence: the idea of an inner nature implies that there is also an outer nature from which the subject is distant, a context in which his cultural existence might take place. The image of an outer nature is hence another aspect of the ideology the film pertains to. More precisely, the notion of a nature "out there" (outside of culture) and "deep down" (inside the subject) are both part of what Timothy Morton calls an ageold agrilogistic apparatus. "What we call modern dualism (the Cartesian self, even better, the transcendental Kantian subject) is just a variant of the agrilogistic attunement.”26 One might even argue that it is only lately that the falseness of this dualism - this "daft idea" to use Morton's words - is becoming apparent as a consequence of what goes under the name of the Anthropocene. Nature is suddenly threatening us, but at the same time we realize that this is a "nature" brought forth by us, by human culture, modernity, progress, domination of nature.

This historic irony is something the film actually brings attention to, through recurring shots of the piste machines, the snow-making machines, the mechanisms of the cableways, the controlled avalanches, the sophisticated architecture of the hotel, the mountain-top restaurants, and so on. If this is "nature," the film tells us, it is also a cultural product, something man made, a commodity. ${ }^{27}$ In order to spend time in nature, we have transformed it into something else.

Following Adorno, one could say that the film thus says nothing at all about nature, but quite a lot about "second nature": "The concept of a second nature remains the negation of whatever might be thought of as a first nature. So, it does not represent the recurrence of a nature, that has been suppressed and is now being restored, but on the contrary it is the totality of whatever has been so completely trapped by social and rational mechanisms ... that nothing differing from it can manifest itself." ${ }^{28}$ Second nature has such a total grip over us that there can no longer be anything that exceeds it, Adorno argues. If there is such a thing as (first) nature, we do not have any access to it, because we are not capable of reaching out of second nature. "[W]hat seems to be outside us is in reality not outside at all," as Adorno writes. ${ }^{29}$ The distinction between nature and culture, ascribing the first one an untouched priority, does not hold - it is the result of the subject projecting itself onto nature - which means that the whole notion of "inside" / "outside" also breaks down, just like Morton argues.

But even if this is the case, it is certainly becoming clearer that there is something beyond our cultural constructions, subjective 
perspectives, and ideological confinements. The temperature is rising, the ice is melting, species are dying. Nature? Well, whatever we want to call it, what appeared to be the passive, stable counterpart of culture and history, is all of a sudden delicate, unstable, active, and just as much culture as nature. This is one way to understand the Anthropocene: as a historical state of nature undeniably brought forth by us - or rather by agrilogistics, capitalism, progress, technology, humanity - at the same time as it exceeds our intentions, interpretations, and possibilities to do much about it. ${ }^{30}$ This implies that not only the relation between history and nature has to be rethought, ${ }^{31}$ but also the understanding of human agency. What we are facing is something beyond our control, produced by our control. Is it perhaps rather culture that is a product of nature? Is "culture" just an anthropocentric misunderstanding?

Intentionally or unintentionally, Force Majeure contains an allegorical dimension mediating this confusion typical to the Anthropocene. Who are we? What are we made of? What is acting when we think we are acting? What is that, which we called nature? Or the culture we thought we were? These categories are certainly hard to keep separate. And accordingly, the "we" is not as autonomous as we, from our Cartesian perspective, imagined. Against that background Tomas' breakdown (“I'm a victim too!") has wider implications. Our cogito, our rationality, our control, our conventions are not really ours after all. We are victims too. But of what? That is the question. Our private little disasters are nothing but a premonition.

The image from Ruben Östlund's film is reproduced with permission and assistance of Plattform Produktion. 
1 Ruben Östlund, "Sommar," radio talk show, Swedish Public Service Radio, P1, August 19, 2017, https://sverigesradio.se/sida/ avsnitt/927254?programid=2071. (Here and in the rest of the paper, translations from Swedish sources are my own).

2 "Borg ber om ursäkt: Fick blackout" [Borg Apologizes: Had a Black Out], unsigned article, Aftonbladet, August 4, 2017.

3 Force Majeure, directed by Ruben Östlund (Sweden: Plattform produktion, 2014).

4 Ruben Östlund, Turist (Umeå: Atrium, 2014), 149.

5 See Butler, Giving an Account of Oneself (New York: Fordham University Press, 2005).

6 Sigmund Freud, "A Difficulty in the Path of PsychoAnalysis," trans. Joan Riviere, in The Complete Psychological Works of Sigmund Freud, Vol. XVII, ed. James Strachey (London: Hogarth Press, 1955), 143.

7 See e.g. "En manlighet i kris" [A Masculinity in Crisis], discussion between Östlund and Lena Andersson at the literary festival Littfest, Umeå, March 13, 2015, https:// www.youtube.com/watch?v=yTx23WgNxSA.

8 See e.g. Jonathan Romney, "Force Majeure review compelling, intelligent and grimly entertaining," The Observer, April 12, 2015; Stephen Holden, "Every Man for Himself! Forget the Wife and Kids," New York Times, October 23, 2014.

9 Wendy Brown, Undoing the Demos: Neoliberalism's Stealth Revolution (New York: Zone Books, 2015), 38.

10 Theodor W. Adorno, Negative Dialectics, trans. E.B. Ashton (New York: Continuum, 1994), 221.

11 René Descartes, Discourse on Method and the Meditations, trans. F.E. Sutcliffe (London: Penguin Books, 1968), 54

12 Ibid., 56.

13 Christian Gullette, who emphasises the ironic dimension in Östlund's work, describes how the film encourages the viewer to "oscillate" between different reactions. See Christian Mark Gullette, Challenging Swedishness: Intersections of Neoliberalism, Race, and Queerness in the Works of Jonas Hassen Khemiri and Ruben Östlund (PhD diss., University of California, Berkeley, 2018), 67.

14 Östlund, "Sommar."

15 Gullette, 69.

16 Ibid., 69.

17 Descartes, 55.

18 Ibid., 58.

19 Étienne Balibar, "Citizen Subject", in Who Comes After the Subject?, ed. Eduardo Cadava, Peter Connor, and Jean-Luc Nancy (New York \& London: Routledge, 1991), 36.

20 Scener ur ett äktenskap, TV-production, directed by Ingmar Bergman, Cinematograph AB, 1973.

21 See Stefan Jonsson, Subject Without Nation: Robert Musil and the History of Modern Identity (Durham \& London: Duke University Press, 2000), chapter 1.

22 Regarding the difficulties of escaping Cartesianism, see Cary Wolf, What is Posthumanism? (Minneapolis: University of Minnesota Press, 2010), xxvii, chapter 2; Slavoj Žižek, The Ticklish Subject: The Absent Centre of Political Ontology (London \& New York: Verso, 1999), 1-2.
23 Jakob Lothe, Etikk i litteratur og film (Oslo: Pax Forlag, 2016), 226.

24 Roger Edholm, "Family Framing and the Comedy of Conventions in Ruben Östlunds Force Majeure,"Nordic Journal of Aesthetics, 55-56, 2018, 116-133.

25 Timothy Morton, Dark Ecology: For a Logic of Future Coexistence (New York: Columbia University Press, 2016), 136-37.

26 lbid., 88.

27 Or as it is described in the published manuscript: "The civilized and planned in midst of the wild and uncivilized nature. No joviality, no farmers culture, a phenomenon created around ski tourism and the nuclear family." Östlund, Turist, 41.

28 Theodor W. Adorno, "Lecture 14. The History of Nature (II)," in History and Freedom: Lectures 1964-65, trans. Rodney Livingstone (Cambridge: Polity Press, 2006), 120.

29 Ibid., 121.

30 Cf Morton, 38-59; Timothy Clark, Ecocriticism on the Edge: The Anthropocene as a Threshold Concept (London \& New York: Bloomsbury Academic, 2015), 1-3; Peter Haff, "Humans and technology in the Anthropocene: Six rules", The Anthropocene Review, no. 2 (2014): 127; Donna Haraway, Staying with the Trouble: Making Kin in the Chthulucene (Durham \& London: Duke University Press, 2016); Chris D. Thomas, Inheritors of the Earth: How Nature Is Thriving in an Age of Extinction (New York: Public Affairs 2017), 196-97.

31 See Dipesh Chakrabarty, "The Climate of History: Four Theses," Critical Inquiry 35, no. 2 (Winter 2009): 201. 